Vol 3 No 1 (2020) 84-88 P-ISSN 2620-295 E-ISSN 2747-0490

DOI: 1047467/elmal.v3i1.516

\title{
Regional Studies: A Comprehensive Implement for Regional Development Planners
}

\author{
Farah Chalida Hanoum. T1, Ria Kusumaningrum² \\ 1IAI Nasional Laa Roiba Bogor \\ ${ }^{2}$ IAI Sahid Bogor \\ farahchalidah@laaroiba.ac.id ${ }^{1}$, rkusumaningrum@inais.ac.id ${ }^{2}$
}

\begin{abstract}
Indonesia represents a particularly interesting country for studying development policies. It is large, being the fifth largest country in the world in population and the thirteenth in land size, geographically separated due to the island nature, and has a highly diverse society with a large number of different ethnic groups, languages and religious. It is also a country that has seen in long history as a struggling nation which never desperate. Regional study on developing countries as whole does not only imply regional economics of the regional entity economics of the regional entity as a whole and interregional connections, but also implies regional development policy and regional development policy and regional development planning.
\end{abstract}

\section{BRIEF INTRODUCTION}

\section{Regional Growth}

As part of the national economy, regions are expected to contribute in an optimal way to overall national growth. Optimal contribution is measured according to national criteria and does not necessarily mean maximum growth of a particular region.

The situation can sometimes lead to a conflict between national and regional interest. This is particularly true in the short run; and in the long run the national economy is interested in full utilization of all production factors regadless of their location.

In order to achieve a maximum and sustained rate overall growth national development efforts concentrate on region with the highest potential to contribute the growth of the national economy. 


\section{Vol 3 No 1 (2020) 84-88 P-ISSN 2620-295 E-ISSN 2747-0490 D0I: 1047467/elmal.v3i1.516}

Also regions with relatively good economic infrastructure have attracted considerable manufacturing activities and in a relatively short time have achieved laudable results in restructuring their economy.

On the other hand, economic development in backward regions with little growth potential has been much slower than in the former ones. Optimal contributions of regions towards national growth result in their growing specialization in those areas of production and services in which each of then processes the most favourable conditions.

Specialization if carried too far, may be detrimental to the development of particular regions; the critical issue here is how far one can go on the path of regional specialization.

\section{Regional Policy}

In most countries, the underdeveloped regions have been backward rural areas with primitive and low agricultural production, and without any significant resources found in those areas. The basic instrument of change should be industrialization initially based mainly on agricultural produces including raw materials resources, and later could also encompassing other manufacturing.

Reforms in agriculture and development in industry, in turn, helped to restructure the primitive settlement system. Growth poles and growth centre of various sizes have gradually emerged, giving the regions further impetus for development.

The implementation of regional policies is predominantly explicit in those spheres of economic and social activity which are directly supervised by local an regional authorities.

The execution of regional policy in an explicit way according to the features describe above, requires an extensive and effective financial and development administration reaching down the local level.

\section{Regional Development Planning}

Regional development planning is a platform upon which regional control guidance. It also represent a mechanism through which a compromise is sought between the long run and short term necessities and limitations of the economy.

A major planning issue throughout the world is the existing gap between socioeconomic planning and urban (physical) planning. To bridge this gap is not an 
Vol 3 No 1 (2020) 84-88 P-ISSN 2620-295 E-ISSN 2747-0490 DOI: $1047467 /$ elmal.v3i1.516

easy task, considering the differences between the two, in content, horizon and methodology of plan preparation.

Finally, it is worth mentioning that the existing system of regional plans is fairly elastic in order to be able to adapt to changing development conditions. It resembles, to some extent, the rolling planning approach (Bohdan Gruchman, 1988).

\section{IMPLEMENTATION OF REGIONAL STUDY AND DEVELOPING COUNTRIES AS A WHOLE.}

\section{Regional Study on Indonesia}

Indonesia represents a particularly interesting country for studying development policies.

It is large, being the fifth largest country in the world in population and the thirteenth in land size, geographically separated due to its island nature, and has a highly diverse society with a large number of different ethnic groups, languages and religions. It is a country that has also seen in its long history, colonization, involvement in world wars, a struggle for independence followed in turn by periods of internal rebellion and political instability that were only resolved with the coming to power of the new order in the late 1960s and the emergence of a stable government. (Collin Mac Andrew, Atar Sibero, H. Benjamin Fisher,1986)

The regional studies on Indonesia's regional development should comprise among others :

1. Physical, cultural and political dimensions in connection with regional development.

2. The history of regional development planning in Indonesia.

3. The provincial area development programme (PADP), compising with :

- Aims importance

- Origin of PADP

- Strategies used in regional development planning

- PADP in practice

- The lessons learned from PADP :

1. Finding

2. Consultans

3. Organization

4. Training

5. Communications

6. Capacity, building

7. Provincial differences 
Vol 3 No 1 (2020) 84-88 P-ISSN 2620-295 E-ISSN 2747-0490 DOI: $1047467 /$ elmal.v3i1.516

4. Future directions comprises :

- Strengthening the bureaucratic apparatus

- Managerial skill

- Continuing focus an local area planning

Regional study on developing countries as a whole does not only imply regional economics of the regional entity as a whole and interregional connections, but also implies regional development policy and regional development planning.

The study on regional development planning comprises the scope as follows :

\begin{tabular}{|c|c|c|}
\hline Territorial Level & Type Of RDP Needed & Focus \\
\hline World & $\begin{array}{l}\text { Multinational studies for } \\
\text { cooperation/coordination }\end{array}$ & $\begin{array}{l}\text { Studies on economic } \\
\text { growth, flow of resources, } \\
\text { quality of life, etc. } \\
\text { development of } \\
\text { resources, agriculture, } \\
\text { industry, infrastructure, } \\
\text { etc. } \\
\text { In order to bring about } \\
\text { more interdependence } \\
\text { among the countries and } \\
\text { to indicate the economic, } \\
\text { ecological and other } \\
\text { benefits from original } \\
\text { cooperation and } \\
\text { coordination. }\end{array}$ \\
\hline National & $\begin{array}{l}\text { Regional structural } \\
\text { analysis and interregional } \\
\text { planning. }\end{array}$ & $\begin{array}{l}\text { Interregional planning } \\
\text { and programming in } \\
\text { order to minimize } \\
\text { regional disparities in } \\
\text { development }\end{array}$ \\
\hline Subnational & $\begin{array}{l}\text { Regional studies, regional } \\
\text { planning within national } \\
\text { frame work and regional } \\
\text { development }\end{array}$ & $\begin{array}{l}\text { To develop the resources } \\
\text { of each region in order } \\
\text { that the quality of life of } \\
\text { the people improved, this } \\
\text { includes } \\
\text { ecodevelopment. }\end{array}$ \\
\hline
\end{tabular}


Vol 3 No 1 (2020) 84-88 P-ISSN 2620-295 E-ISSN 2747-0490 DOI: 1047467/elmal.v3i1.516

\begin{tabular}{|l|l|l|}
\hline $\begin{array}{l}\text { Local level } \\
\text { (microregional level) }\end{array}$ & $\begin{array}{l}\text { Community studies, micro } \\
\text { regional planning }\end{array}$ & $\begin{array}{l}\text { Popular participation, } \\
\text { social development, self } \\
\text { reliance and local } \\
\text { resource development. }\end{array}$ \\
\hline
\end{tabular}

\section{Conclusion}

Regional study on developing countries as a whole does not only regional economics of the regional entity as a whole and interregional connections, but also implies regional development policy and regional development planning.

\section{REFFERENCES}

Bohdan Gruchman, Relevance of Regional Economics to Centrally Planned and Developing Countries, In Regional Development : Essay in Honour of Masahiko Honjo, Maruzen Asia, 1988.

Mac Andrews C, Sibero A, Fisher H. B, Regional Development Planning and Implementation in Indonesia : The Evolution of a National Policy in Regional Development : Essays in Honour of Masahiko Honjo, Maruzen Asia, 1986.

Misra R.P., Regional Development : Essays in Honour of Masahiko Honjo, Maruzen Asia, 1982.

Mohammad Gandhi Wirananggapati, Some Technical Aspects and Mechanism of Agricultural Development Planning as an Integral Part of Regional Development Planning. A Comparative and case study of Bicol Region (Philippines) and the region of Papua, 2008. 